UDC 2-737(477+476):930(470+571)«18/19»

DOI: $10.24919 / 2519-058 x .7 .131618$

Vasyl MEN'KO,

orcid.org/0000-0002-9528-547X

Senior Lecturer, Ivan Franko Drohobych State Pedagogical University

(Ukraine,Drohobych)vasulmenko@gmail.com

\title{
THE ORIGIN AND ONTOGENESIS OF ORTHODOX CHURCH BROTHERHOODS IN UKRAINE AND BELORUSSIA IN THE WORKS OF REPRESENTATIVES OF RUSSIAN HISTORICAL SCIENCE (the 1850s - beginning of the XX century)
}

The article presents an analysis of scientific achievements of the historians of the Russian historical school of the second half of the XIX century and their contribution into the study of the problem of origin of the Orthodox church brotherhoods of Ukraine and Belarus.

Key words: brotherhood, metropolitan, church.

Василь МЕНЬКО, стариий викладач

Дрогобииького державного педагогічного університету імені Івана Франка (Украӥна, Дрогобич) vasulmenko@gmail.com

\section{ГЕНЕЗА ТА ПОХОДЖЕННЯ ПРАВОСЛАВНИХ ЦЕРКОВНИХ БРАТСТВ УКРАЇНИ І БІЛОРУСІЇ У ПРАЦЯХ ПРЕДСТАВНИКІВ РОСІЙСЬКОӤ ІСТОРИЧНОЇ НАУКИ (50-ті рр. ХІХ - поч. ХХ ст.)}

У статті проаналізовано науковий доробок та внесок істориків російської історичної школи другої половини XIXст. у вивчення проблеми походження православних иерковних братств України і Білорусії. Доведено, що російські історики православної історіографічної школи акцентували увагу переважно на релігійних формах функціонування братств і сферах діяльності, які сприяли змічненню $і$ захисту православ'я. Висвітлено особливості розвитку історіографії в контексті тогочасних умов розвитку, показано основні напрямки та досягнення.

Ключові слова: братства, митрополія, иерква.

The statement of the problem. The phenomenon of church brotherhoods alias religious secular organisations of Ukraine and Belorussia of the early modern time (XVI XVIII centuries) has always drawn the attention of researchers. Hence, in scientific literature the problems connected with the origin of brotherhoods, their typology, granting stauropegional (autonomous) rights, conflicts with hierarchy, and the reasons of a long and cruel struggle against the Unia were mostly discussed. Almost all historians of early modern church and culture paid much attention to these problems, and their works contained historiographic reviews of the problems.

The analysis of the researches. By today in a great mass of historical literature the original works enlightening the phenomenon of brotherhood movement on Ukraine's territory are not numerous. M. Kapral in his review of S. S. Lukashova's monograph justly remarks: «Since the publication in 1966 of the known Yaroslav Isaievych' book Brotherhoods and their role in the developments of Ukrainian culture in the XVI- XVIII centuries», separate 
publications almost did not change the situation, and so, in the estimation of this phenomenon old values dominated (Kapral, 2007:133-144).

However, this does not mean that this question has not been investigated hitherto or that it has no historiography. The elaboration of separate political, historical-legal, social, and economical plots from the history of Orthodox church brotherhoods, and historiographic problems were treated in the work of many researchers. Among them the following deserve mentioning: B. Lorens (Lorens, 2005), O. Fefelova (Fefelova, 2001), S. Lukashova (Lukashova, 2006), and others.

The purpose of this article is to analyze the historiographic achievements devoted to theories on the origin of Orthodox brotherhoods, to find out the basic directions and tendencies of the development of the theme, to define little studied and non-studied questions of the problem under consideration.

The statement of the basic material. In the $1850 \mathrm{~s}-1870$ s the problem of the origin of church brotherhoods of Ukraine and Belorussia became a research subject of major importance for Russian historical science representatives. It was raised by A. Popov's publication of his book «Feasts and Bratchyny» (Popov, 1854) in which the author considered a custom to arrange a general banquets on the temple holiday: «the Community gave banquets which were also known as bratchyny. The link of the banquets with holidays specifies their religious value, but the fact that games, dances, and songs which accompanied those banquets testify to their pagan origin» (Popov, 1854:21).

If at a banquet there was a fight or murder, the community acted as the public court (Popov, 1854:33). His theory of the genealogic unity of all East Slavic peoples has defined a new direction of historical researches.

Separate Russian historians, such as V. Kliuchevskyi (Kliuchkovskyi, 2004), V. Solovyov (Solovyov, 1856), and others, connected the origin of brotherhoods with the existence on the northeast lands of Rus' of old Rus' bratchyny. From that theory it followed that the Ukrainian brotherhoods became a direct continuation of the bratchyny of Rus' since the times immemorial, that is, they were not a historical and cultural phenomenon characteristic for Ukraine only.

That imperial Russian theory ignored the essential differences in living conditions between Northeast Rus' on the one hand, and Ukraine and Belorussia on the othe hand, it did not also take into consideration the the chronological factor (as is known, Old Rus' bratchyny were active mainly in the XII - XIII centuries and, consequently, that is why to speak about an unequivocal continuity between them and the Ukrainian brotherhoods which developed almost two hundred years later, is rather problematical). In the activity of brotherhoods the aforementioned historians singled out two periods, namely, one prior to the middle of the XVI century and a later one, but they did not determine a principle difference between bratchyny and church brotherhoods.

Metropolitan Philaret (Humyliovskyi) also allocated two periods in the activity of brotherhoods. During the first one, the brotherhood were engaged mainly in the care of buildings and maintenance of the clergy and the poor (Philaret (Humyliovskyi), 1847:25). Metropolitan Philaret's work contains a great number of factological errors.

Thus, he asserted that Lviv Stauropegion was founded «thanks to the promotion of Gedeon, a Lviv bishop and a well-known advocate of Orthodoxy» (Philaret (Humyliovskyi), 1847:96): and that was said contrarily to the fact, that many documents testifying to a serious conflict between the brotherhood the bishop survived.

I. Flerov's monograph (Flerov, 1857) is dedicated to the history of church brotherhoods, essentially differs from the works of his contemporaries. He saw the source of the origin of 
church brotherhoods in early Christian communities, considering, like Metropolitan Philaret, the cause of the appearance of brotherhoods (confraternitates) movement as the necessity of struggle against the Catholic propaganda. In the favour of in I. Flerov wrote the following: everywhere Church societies or brotherhoods started to be established, which members by oath promised to firmly stay in the belief of their fathers and by all efforts to oppose the stream of Roman-Catholic split. It was then that in all the provinces of southwest Russia the brotherhoods of Lviv, Vilnius, Kiev, Pinsk, Orshansk, Brest, Lutsk, Mohiliov, Belz, Minsk, as well as many others arose (Flerov, 1857:12).

Further on the researcher analyzes also other reasons of appearance of brotherhoods. $\mathrm{He}$ sheds some light on the problem of their form organization, from whom they could inherit the very idea of brotherhood formation, and in what primary kind it had existed.Another task that the historian assumes is how the Polish kings and, in general, the Polish government could have admittedthe very existence of brotherhoods?

I. Flerov comes to a conclusion that «brotherhoods must have arisen from the structure of that time society, or, at least, should have found for themselves a support among the civil establishments of that time» (Flerov, 1857:14). The scientist assumed that craft guilds might have been a reason to cause the appearance of church brotherhoods, besides, on it the establishment of Magdeburg law had a direct influence.

The great number of the facts telling about the activity of church brotherhoods in Rzeczpospolita's cities which were guided on the basis of Magdeburg law, do not raise any doubts. Even the kings, whom hated the very existence of those brotherhoods, could not forbid them, because they represented the organisations which got under protection of the Magdeburg law.

Putting forward his hypothesis that the Orthodox inhabitants of southwest Rus' had borrowed the idea of formation of brotherhoods from the gilds, the author makes the following remark: «As is known, all handicraftsmen, no matter of religious distinctions, belonged to the guilds. But as an aftermath, about 1458, handicraftsmen of the Orthodox confession began to form societies within their milieu or brotherhoods» (Flerov, 1857:18).

Flerov's work became a major landmark in Russian historiography, having initiated the direct research of the role of Orthodox church brotherhoods in many vital spheres of the Ukrainian historical process.

Similarly to I. Flerov, M. O. Koyalovych in his book «Lithuanian church union» puts forward another of the origin of brotherhoods, considering that craft shops were the direct samples for the appearance brotherhoods (Koyalovych, 1859:65).

Still another version of the origin of brotherhoods in 1875 was put forward by the senior lecturer (later, professor) Mykola Afanasiyovych Skabalanovych (Skabalanovych, 1875:271-287) He asserted that the Orthodox brotherhoods copied the West European guilds and Catholic brotherhoods, but the arguments he used in his statement's support are rather inconsistent. Without making any particular dwelling on that subject, the author sticks to his hypothesis about the origin of both the Orthodox brotherhoods and European guilds from pagan sources.

The researcher asserted that, at first, the people who gathered for a feast, both in Rus' and in Germanic countries, had no particular obligations one to another. "In due course, such obligations appeared - to help maintain one another and the church in difficult circumstances, festive meetings turned to unions, guilds, corporations of people» (Skabalanovych, 1875:274).

However, this point of view did not receive a wide circulation within the historical science of the XIX - beginning of the XX century. 
In the 1890s the church historian O. Papkov publishes a number of articles in the «Theological Herald» devoted to the history of the Ukrainian and Belorussian brotherhoods (Papkov, 1891:166-188). In 1900 A. Papkov's larger special work about brotherhoods was published (Papkov, 1900). Despite the broad chronological span (from the princely time to the end of the XVIII century), its problem statement should be considered as very careful. The historian suggested his periodization of the history of brotherhoods. The period between 1586 and 1600 he called an epoch of transformations, the period within 1600 and 1620 was called the period of powerful protection of Orthodoxy by brotherhoods. The author also formulated an important definition, namely, that «brotherhoods were large Christian unions with wide educational and charitable purposes» (Papkov, 1901:1083-1108).

A. Papkov also formulated the thought that the appearance of brotherhoods had introduced in Orthodox societies «the Church-social system», granted by patriarchs. In the author's opinion, several positions put forward and proved by the researcher are still of great value despite their conditionality.

Already in A. Papkov's works the problem of the role of laymen in the church, who, headed by prince K. Ostroz'kyi, lead the Kievan Metropoly out from a deep crisis. At the mentioned background, the role of brotherhoods as circular organisations was derived quite naturally (and, accordingly, in a very much simplified way) (Papkov, 1900:LV). The accentuation of secular forms in the activity of brotherhoods was very convenient for Russian historiography in respect of a more relief display of the struggle of the «Russian people» against the Catholicism and Unia. Considering that the education level was enough high in the last third of century, he connects it with the formation of brotherhoods as «educational-charitable» unions. The researcher also accentuated on the role of petty bourgeois in the activity of the Lviv brotherhood, underlining at, the same time, a considerable quantity of magnates and szlachta within the structure of the Vilnius brotherhood..

In the middle of the XI century, right after the publications of the first materials on the history of Lviv and other brotherhoods, in Russian historiography a polemic about the origin of these organisations developed. The beginning of the discussion was initiated by S. Solovyov who put forward the theory of the brotherhoods origin in the end of the XVI-XVII centuries from the Old Rus' «bratchyny», known from the XII century (Solovyov, 1856:108). At the same time, Solovyov considered that the further development of brotherhoods had been influenced by the guilds and city self-management according to the Magdeburg law.

An original theory of the origin of brotherhoods was suggested by O. Y. Yefymenko, according to whom all brotherhoods and similar organisations derive from from one «parental form» of clan brotherhood (Yefymenko, 1905:200-309). For the first time the Ukrainian and Belorussian brotherhoods were considered as a part of one all-European process. Investigating materials on histories of the clan unions of the Slavs, Germans and Scandinavians, Yefymenko came to a conclusion that the West European guild, the craft shop, the Old Rus'bratchyna, and the church brotherhood were the homogeneous phenomena and derive from patrimonial unions. Yefymenko not only connected the Ukrainian brotherhoods with the similar unions in other European countries, but also traced back their development and evolution up to the XI century.

Thus, the researcher has created a certain extra-historical abstraction from which all peculiar features of brotherhoods existing at various times which had absolutely different problems have been eliminated.

From the theoretical point of view L. Karsavin's works are very interesting, despite the fact that Ukrainian church brotherhoods were not the subject of his researches. He was the 
first in Russian historiography to offer the characteristic of a medieval brotherhoods of Western Europe (Karsavin, 1992:143-149). According to the researcher, brotherhoods are the organisations of laymen which should be considered within the framework of the history of monks, as they represent a form of «weakened asceticism» and display the ideals of some or other sides of religious life of their epoch' (Karsavin, 1992:148).

As well as the representatives of the Ukrainian church historiography, Russian researchers of the Orthodox historiographic school have focused their attention mainly on religious forms of functioning of brotherhoods, whereas the historians of the so called university school have shown an interest in the problem of the origin of brotherhoods and their contribution into the development of public thought and culture.

The conclusion. Summing up the available stock of researches ion the history and theory of the origin of the Orthodox brotherhoods, it is necessary to note that Russian historians of the Orthodox historiographic school focused their attention mainly on religious forms of brotherhoods' functioning and in such fields of activity which assisted in strengthening and protection of the Orthodoxy.

The works of Russian historians of the second half of the XPX c. became a major landmark in the history of Russian historiographic thought as these works initiated a comprehensive investigation of the theories of the origin of brotherhoods in Ukraine and Russia.

\section{BIBLIOGRAPHY}

Ефименко, 1905 - Ефименко О. Я. Южно-русские братства // Южная Русь. СПб., 1905. Т. 1. 367 с. Капраль, 2007 - Капраль М. «У своєму соку» або чи є вартісним дослідження без архівних джерел. // Український гуманітарний огляд. Київ, 2007. Вип. 13. С. 133-144.

Карсавин, 1992 - Карсавин Л.П. Монашество в средние века. Москва., 1992. 453 с.

Ключковський, 2004 - Ключквський В.О. Боярская дума Древней Руси. М., 2004. 470 с.

Коялович, 1859 - Коялович М.О. Литовская церковная уния. СПб., 1859. Т. 1. 275 с.

Лукашова, 2006 - Лукашова С.С. Миряне и церковь: религиозные братства Киевской митрополии в конце XVI века. М., 2006. 321 с.

Папков, 1891 - Папков А.А Охранительная деятельность православных братств в последнии годы царствования короля Сигизмунда III: 1620-1632 // Богословский весник. 1891. № 5. С. 166-188.

Папков, 1901 - Папков А.А. Братства // Православная богословская энциклопедия или Богословский энциклопедический словарь. Под ред. проф. А.П. Лопухина. Т. 2. Петроград, 1901. C. $1083-1108$.

Папков, 1900 - Папков А.А. Братства. (Очерк истории западнорусских православных братств). М., 1900. - 753 с.

Попов, 1854 - Попов А. Пиры и братчины // Архив историко-юридических сведений относящихся до Росси. Изд. Н. Качаловым. М., 1854. Кн. 2. Пол. 2.

Скабаланович, 1875 - Скабаланович Н. Западноевропейские гильдии и западно-русские братства // Христианские чтения. 1875. № 9-10. С. 271-287.

Соловьєв, 1856 - Соловьєв С.М. Братчины // Русская беседа. 1856. № 4. С. 108-117.

Успенське братство і його роль в українському національно-культурному відродженні. Доповіді та повідомлення науковї конференції 5 квітня 1996 р. Львів, 1996.

Фефелова, 2001 - Фефелова О. А. Православные братства на восточнославянских территориях Речи Посполитой во второй половине XVI - первой половины XVII веков // Автореф. дис. канд. ист.наук. Томск, 2001. 20 с.

Филарет (Гумилевский), 1847 - Филарет (Гумилевский), митр. История русской церкви. М., 1847. T. 3. C. 25 .

Филарет (Гумилевский), 1847 - Филарет (Гумилевский), митр. История русской церкви. М., 1847. T. 4. C. 96

Флеров, 1857 - Флеров И. О православных церковных братствах, противоборствовавших унии в фго-западной Росии в XVI, XVII, XVIII столетиях. СПб., Изд. Книгопродавца Н. Г. Овсянникова. 1857. 200 с. 
Lorens , 2005 - Lorens B. Bractva cerkiewne w eparchii przemyskiey w XVII - XVIII wieku.Wyd awnictwoUniwersytetuRzeszowskiego. Rzeszów, 2005. 336 s.

\section{REFERENCES}

Efymenko, 1905 - Efymenko O.Ia. Yuzhno-russkye bratstva [The brotherhoods of southern Rus'] // SouthernRus'. SPb., 1905. T. 1. 367 p. [in Russian]

Kapral, 2007 - Kapral M. «U svoiemu soku» abo chy ye vartisnym doslidzhennia bez arkhivnykh dzherel. [«It one's own juice», or whether theresearch without archival sourcesis valid] // Ukrainian humanitarian review. Kyiv, 2007. Vyp. 13. Pp. 133-144. [in Russian]

Karsavyn, 1992 - Karsavyn L.P. Monashestvo v srednye veka. [Monkhood in Middle Agea]. Moskva., 1992. 453 p. [in Russian]

Kliuchkovskyi, 2004 - Kliuchkvskyi V.O. Boiarskaia duma Drevnei Rusy.[TheBoyarDumaof Ancient Rus']. M., 2004, 470 p. [in Russian]

Koialovych, 1859 - Koialovych M.O. Lytovskaia tserkovnaia unyia. [LithuanianChurchUnion]. $\mathrm{SPb} .$, 1859. T.1. 275 p. [in Russian]

Lukashova, 2006 - Lukashova S. S. Myriane y tserkov: relyhyoznye bratstva Kyevskoi mytropolyy v kontse XVI veka. [Laymenand the Church: religious brotherhoods in Kiev metropoly in the end of XVI c.]. M., 2006. 321 p. [in Russian]

Papkov, 1891 - Papkov A.A Okhranytelnaia deiatelnost pravoslavnykh bratstv v poslednyy hody tsarstvovanyia korolia Syhyzmunda III: 1620 - 1632 Protectionactivity of the Orthodox brotherhood sin the last years of there ignof King Sigismund III: 1620 - 1632] // Theologianherald. 1891. № 5. Pp. 166-188. [in Russian]

Papkov, 1901 - Papkov A. A. Bratstva // Pravoslavnaia bohoslovskaia entsyklopedyia yly Bohoslovskyi entsyklopedycheskyi slovar. [TheOrthodoxtheologianencyclopediaorTheologianencycl opedian dictionary].Pod red. prof. A. P. Lopukhyna. T. 2. Petrohrad, 1901. Pp. 1083-1108. [in Russian]

Papkov, 1900 - Papkov A.A. Bratstva. (Ocherk ystoryy zapadnorusskykh pravoslavnykh bratstv). [Brotherhoods. (Asketchofthehistoryof west Rus'Orthodox brotherhoods)]. M., 1900. 753 p. [in Russian]

Popov, 1854 - Popov A. Pyry y bratchyny // Arkhyv ystoryko-yurydycheskykh svedenyi otnosiashchykhsia do Rossy. [Archiveofhistorical-juridicalinformation concerning Russia.]. Yzd. N. Kachalovym. M., 1854. Kn. 2. Pol. 2. [in Russian]

Skabalanovych, 1875 - Skabalanovych N. Zapadnoevropeiskye hyldyy y zapadno-russkye bratstva [WestEuropenguildsandwesternRus' brotherhoods] // Christianreadings. 1875. № 9-10. Pp. 271-287. [in Russian]

Soloviev, 1856 - Soloviev S.M. Bratchyny [Bratchiny] // Russian conversation. 1856. № 4. S. 108-117. [in Russian]

Uspenske bratstvo i yoho rol v ukrainskomu natsionalno-kulturnomu vidrodzhenni. Dopovidi ta povidomlennia naukovi konferentsii 4-5 kvitnia [TheDormitionBrotherhoodanditsrolein Ukrainian national and cultural revival. Reportsandspeechesof the scientific conference of 4-5 April 1996]. 1996 r. Lviv, 1996. [in Ukrainian]

Fefelova, 2001 - Fefelova O. A. Pravoslavnye bratstva na vostochnoslavianskykh terrytoryiakh Rechy Pospolytoi vo vtoroi polovyne XVI - pervoi polovyny XVII vekov [Orthodoxbrotherhoodsinthe eastSlaviclandsofthePolishRepublicinthesecondhalfoftheXVI - firsthalfoftheXVIIcenturies] // Avtoref. dys.kand. yst.nauk. Tomsk, 2001. 20 p. [in Russian]

Fylaret (Humylevskyi), 1847 - Fylaret (Humylevskyi), mytr. Ystoryia russkoi tserkvy. [History of Russian Church]. M., 1847. T. 3. P. 25. [in Russian]

Fylaret (Humylevskyi), 1847 - Fylaret (Humylevskyi), mytr. Ystoryia russkoi tserkvy. [History of Russian Church]. M., 1847. T. 4. P. 96. [in Russian]

Flerov, 1857 - Flerov Y. O pravoslavnykh tserkovnykh bratstvakh, protyvoborstvovavshykh unyy v fho-zapadnoi Rosyy v XVI, XVII, XVIII stoletyiakh.[ OntheOrthodoxbrotherhoods, whichollosedtheUniainsoeth-westernRussia in the XVI, XVII, and XVIIIcenturies.] SPb., Yzd. Knyhoprodavtsa N.H. Ovsiannykova. 1857. 200 p. [in Russian]

Lorens, 2005 - Lorens B. Bractva cerkiewne w eparchii przemyskiey w XVII - XVIII wieku. Wydawnictwo Uniwersytetu Rzeszowskiego. [Church brotherhoods in Peremyshl eparchies in the XVIIXVIII centuries]. Rzeszów, 2005. 336 p. [in Polish]

Стаття надійшла до редакиії 10.04.2018 р. 